\title{
religion

\section{Egyptian Activism against Female Genital Cutting as Catachrestic Claiming}

\author{
An VAn RAEMdoncK*
}

\begin{abstract}
This paper deals with questions of the politics of location in knowledge and norm production within the context of Egyptian feminist activism for abandoning female genital cutting practices. It seeks to determine underlying schemes of international campaigning discourse and analyzes how these predicate and complicate Egyptian postcolonial activism. It draws on a broad literature study in addition to fieldwork in Cairo consisting of in-depth interviews with activists and policy makers. My focus is on the national Task Force against FGM from 1994 until 1999 and its subsequent cooptation by the National Council of Childhood and Motherhood. I argue through the concept of catachresis that location matters in setting the terms of anti-FGC discourse and its relation to religion.
\end{abstract}

\section{Keywords}

Postcolonial theory; feminism; female genital cutting; politics of knowledge; Egypt.

\section{Author affiliation}

An Van Raemdonck is doctoral candidate funded by the Research Foundation Flanders. She is based in the Centre for Intercultural Communication and Interaction $(\mathrm{CICl})$, at the Department of Languages and Cultures of Ghent University.

* Correspondence: Rozier 44, 9000 Gent, Belgium. E-mail: an.vanraemdonck@ugent.be This work is licensed under a Creative Commons Attribution License (3.0) Religion and Gender | ISSN: 1878-5417 | www.religionandgender.org | Igitur publishing 


\section{Introduction}

My aim in this article is to look at the epistemological-ontological nexus of assumptions underlying the global anti-FGM/C campaign. I argue that postcolonial theory and the concept of catachresis offer valuable insights for understanding the importance of location in knowledge production and the subsequent complex positioning of local, Egyptian activists and feminists who work for societal change and abandonment of the practice. My focus is on the intricacies of Egyptian activism against FGC and the interplay of global and local dynamics. The article shows how activists have to manoeuvre to carve out their own space within the context of Western-scripted international anti-FGC discourse and an authoritarian state.

This analysis builds on postcolonial theorist Gayatri Spivak's conceptualizations of the notion of 'catachresis' to argue that it is crucial to look at particular historical-spatial frames of knowledge production and global consensus building in order to understand the complexities of local, Egyptian, activism. The first part of the paper surveys literature in order to examine the conditions that have enabled and created the sentiments and discourses that seek to turn the eradication of the practice of FGC into a global norm. In the second part I draw from my fieldwork in Cairo in order to discuss the nature of Egyptian activism protesting against the practice. My focus is on the 1990s national 'Task Force against FGM', its disbandment and the subsequent cooptation of the cause of fighting FGC by the National Council of Childhood and Motherhood (NCCM). I argue that Western-scripted hegemonic discourse production on the practice of FGC has both enabled the work of Egyptian activists and at the same time complicated and limited their activities and position towards the state and society.

\section{Anti-FGM Discourse and its Critiques}

Questions of power relations and historical-spatial frames of knowledge production underlie the following discussion of Egyptian anti-FGC activism. These questions are also central in Spivak's conceptualization of catachresis that I will build on. In her article 'Translation as culture', Spivak uses the concept of catachresis to refer to the process of creating new meaning by slightly deviating from the original meaning. ${ }^{1}$ This manner of proceeding is, importantly, a necessary process. The only way to denounce the new meaning is by deflecting the hegemonic meaning into an alternate, subaltern, meaning. In an earlier piece, 'Poststructuralism, Marginality, Postcoloniality and Value', however, catachresis is presented as a particular post-colonial strategy grounded in political-cultural history. ${ }^{2}$ Here it refers to the making of political claims that rely on, but which also deliberately misuse or abuse concepts and language resulting from the colonial encounter. Spivak argues that:

G.C. Spivak, 'Translation as Culture' in Parallax 6:1 (2000), 13-24.

2 G.C. Spivak, 'Poststructuralism, Marginality, Postcoloniality and Value' in P. Collier and H. Geyer-Ryan (eds.), Literary Theory Today, London: Polity Press 1990, 219-244.

Religion and Gender vol. 3, no. 2 (2013), pp. 222-239 
whatever the identitarian ethnicist claims of native or fundamental origin...the political claims that are most urgent in decolonized space are tacitly recognized as coded within the legacy of imperialism: nationhood, constitutionality, citizenship, democracy, even culturalism....They're being reclaimed, indeed claimed, as a concept-metaphor for which no historically adequate referent may be advanced from postcolonial space, yet that does not make the claims less important. A concept-metaphor without an adequate referent is a catachresis. ${ }^{3}$

The assertion here is that these claims are encoded within an imperialist legacy as the historical specific script in which they are expressed, regardless of whether these concepts resonate globally and express universally desired goods. In what follows the article discusses the claim to abandon the cultural practice of FGC within a postcolonial, Egyptian context as a catachrestic claim. Female genital cutting practices are deeply rooted cultural practices in parts of Africa and are also present in parts of the Middle East and Asia. African feminists and activists who wish to change and abandon this practice find themselves confronted with few 'adequate referents' to support and legitimate an abrogation of this practice and the cultural-symbolic order that it represents. They usually resort to a hegemonic narrative of anti-FGC campaigning that has historically been written in a Western script of modernization, civilization and liberal individualism. The question is raised what it may mean for certain Egyptian activists to rely on and be dependent on Western-scripted anti-FGC discourse. I focus on their personal negotiation and the limits they encounter within aid-structures to illustrate how catachrestic claims are being made. It is argued that these claims are catachrestic because they are inevitably embedded in western hegemonic anti-FGC discourse whilst nonetheless appropriating, moderating, and transforming certain aspects of this discourse in the service of local activism. The first part of this paper considers what it means to speak of a politics of location in knowledge production within the context of the global norm of fighting against female genital cutting practices. It begins with a genealogical outline of the epistemological foundations of anti-FGC discourse that succeeded in turning the 'fight against FGC' into a global and normative discourse. This brief overview sketches the particular contexts in which the practice has been debated, problematized and raised as a global point of action. Two distinct periods stand out: the early 20th century when the British colonial administration first initiated efforts to criminalize the practice and secondly, the second-wave feminist condemnation of the practice from the late 1970s onwards. Both episodes exhibit understandings of female genital cutting as backward and harmful and these critiques form the background against which the consensus-building processes of United Nations institutions have been led, resulting in an internationalist condemnation of the practice as a violation against women and children's rights.

\section{Colonial Discourse, Feminism, and Female Genital Cutting Practices}

Western interest in campaigning against the practice of female genital cutting first emerged during British colonization and the arrival of Christian missions in Africa. The British colonial administrations in Sudan and Kenya developed

3 Ibid., 225. 
policies and legislation to reduce or eliminate what they saw as barbarous and backward customs. ${ }^{4}$ This concern was part of a larger preoccupation with women, their bodies and health, child rearing and children's upbringing. A major reason for trying to change the practice of FGC and infibulation in Sudan in the 1920s was the colonial administration's concern for the consequences of the practice on women's fertility. Janice Boddy argues that colonial efforts against the practice are best understood within a wider population policy. Worried about declining population growth rates, the British aimed at eliminating infibulation and modernizing midwifery training in order to assure human reproduction and to increase the Empire's production in the world market. ${ }^{5}$ Policing and controlling women's bodies and reproductive capacities took a central position in a larger endeavour to control culture and society at large.

In colonial Sudan the subject of FGC became most heavily politicized after the introduction of legislation banning the practice in 1946. Mahmoud Mohammed Taha, the renowned Sudanese Islamic reformist, led the Rufa'a revolt against the British in defiance of the new law banning the practice. ${ }^{6}$ Thomas, Njambi and Pedersen present a similar politicization of the issue in various episodes of Kenyan colonial and postcolonial history. ${ }^{7}$ Also in Kenya the rejection of the practice by Christian missions and British officials brought about fierce resistance by Kenyan women and nationalist leaders. The missionaries' aversion of the practice in combination with the general societal destabilizing effects of colonization even reinforced the practice and gave it new meaning. Remarkably, women played an important role in both the Kenyan and Sudanese 'female circumcision crises'. The wives of British officials, English female parliamentarians and feminist and humanitarian groups all became involved in rallying support for the eradication of the practice. ${ }^{8}$

Colonial attempts were largely ineffective in reversing the practice and most of these efforts were abandoned during the 1950s. For about twenty years, FGC would not receive major attention in the West. It was against the backdrop of second wave feminism and the United Nations 'Decade of Women' (1975-1985)

\footnotetext{
4 J. Boddy, 'Barbaric Custom and Colonial Science' in The Ahfad Journal 23:2 (2006), 81-106; J. Boddy, Civilizing Women: British Crusades in Colonial Sudan, Princeton: Princeton University Press 2007; W.N. Njambi, 'Irua Ria Atumia and Anti-Colonial Struggles Among the Gikuyu of Kenya: A Counter Narrative on "Female Genital Mutilation"' in Critical Sociology 33:4 (2007), 689-708; L. Thomas, 'Ngaitana (I Will Circumcise Myself): Lessons from Colonial Campaign to Ban Excision in Meru, Kenya' in B. Shell-Duncan and Y. Herlund (eds.), Female Circumcision in Africa: Culture, Controversy and Change, Boulder: Lynne Rienner Publishers 2000, 129-150; L. Thomas, "The Politics of the Womb': Kenyan Debates over the Affiliation Act' in Africa Today 47:3/4 (2000), 153.

5 Boddy, 'Barbaric Custom and Colonial Science', 84.

6 A.A. Ibrahim, "Keep These Women Quiet': Colonial Modernity, Nationalism, and the Female Barbarous Custom' in Hawwa: Journal of Women of the Middle East and the Islamic World 9:1/2 (2011), 97-151.

7 Thomas, 'Ngaitana (I Will Circumcise Myself)'; Thomas, 'The Politics of the Womb'; Njambi, 'Irua Ria Atumia and Anti-Colonial Struggles Among the Gikuyu of Kenya'; S. Pedersen, 'National Bodies, Unspeakable Acts: The Sexual Politics of Colonial Policymaking' in The Journal of Modern History 63:4 (1991), 647-680.

8 Thomas, 'Ngaitana (I Will Circumcise Myself)', 132; Pedersen, 'National Bodies, Unspeakable Acts', 654-660.
}

Religion and Gender vol. 3, no. 2 (2013), pp. 222-239 
that the practice of female genital cutting received worldwide attention again. It is well known in feminist circles how North-American feminists Fran Hosken and Mary Daly raised the issue of FGC as part of their view on the global patriarchal control over women. Their accounts have often served as examples of the perpetuation of a colonial feminism that victimizes, generalizes and homogenizes 'Third-World women'. ${ }^{9}$ Chandra Talpade Mohanty, for example, has criticized Hosken and Daly for discursively creating the category of 'backward third-world woman' through their accounts of FGC and FGC-practicing cultures.

Anthropologist Janice Boddy, who has conducted many years of fieldwork in Sudan, points out how the focus has shifted. ${ }^{10}$ She argues that 'while in the late 19 th and 20th centuries, women's essence was associated with childbearing and the womb; from the mid-20th century on...it has come to focus on the clitoris as a site of sexual pleasure, signifying the unencumbered individual relative to the world." ${ }^{11}$ Popular and political discourses informing anti-FGC campaigns saw a similar shift in focus. In the colonial period, infibulation and its consequences for childbirth were targeted while starting from the 1970s emphasis was placed on clitoridectomy and its consequences for sexual fulfilment. Attention on the womb had shifted to a focus on the vagina and the clitoris. Cultural changes and different perceptions of bodily experience in the West became reflected in both astonishment at and repugnance for the practice of FGC.

Despite a shift in focus, however, anti-FGC discourse as it developed in the 1970 s bore a resemblance to colonial attitudes. ${ }^{12}$ Gosselin discusses how colonial discursive practices against FGC were re-invoked by feminist writers and campaigners despite their good intentions. ${ }^{13}$ The practice was mostly presented in an historical and decontextualized manner. Particular meanings, beliefs and values associated with the varied genital operations were dismissed as 'tradition' and thus easily 'equated with "ignorance", "superstition" - and one is tempted to read "backwardness"'. ${ }^{14}$ Gosselin and Kirby note how the significance of culture has been cast aside or at best very naïvely understood by feminists. Gosselin describes this process as 'the trivialization of culture in the political literature', in an effort to ban the practice. ${ }^{15}$ The use of dichotomies such as 'barbaric' vs.

\footnotetext{
9 F.P. Hosken, The Hosken Report, Genital and Sexual Mutilation of Females, 4th rev. ed., Lexington: Women's International Network News 1993; M. Daly, Gyn/Ecology: The Metaethics of Radical Feminism, Boston, MA: Beacon Press 1987; C.T. Mohanty, Feminism without Borders: Decolonizing Theory, Practicing Solidarity, Durham and London: Duke University 2003; U. Narayan, Dislocating Cultures: Third World Feminism and the Politics of Knowledge, Routledge: London and New York 1997.

10 J. Boddy, 'Gender Crusades: the Female Circumcision Controversy in Cultural Perspective' in Y. Hernlund and B. Shell-Duncan (eds.), Transcultural Bodies: Female Genital Cutting in Global Context, Piscataway, NJ: Rutgers University Press 2007, 47.

${ }^{11}$ Ibid., 56.

12 Boddy, 'Gender Crusades'; C. Gosselin, 'Feminism, Anthropology and the Politics of Excision in Mali: Global and Local Debates in a Postcolonial World' in Anthropologica 42:1 (2000), 43-60; V. Kirby, 'On the Cutting Edge: Feminism and Clitoridectomy' in Australian Feminist Studies 2:5 (1987), 35-55.

${ }^{13}$ Boddy, 'Gender Crusades', 53; Gosselin, 'Feminism, Anthropology and the Politics of Excision in Mali', 43-60.

${ }^{14}$ Gosselin, 'Feminism, Anthropology and the Politics of Excision in Mali', 48.

15 Ibid.
} 
'civilized' has long served to legitimate imperialist action and colonial rule. A common understanding of progress, development and social evolution undergirds both periods of anti-FGC discourse whereby 'traditional practices' clearly fall in the domain of uncivilized. ${ }^{16}$ This ontological-epistemological background enabled Western activists to assume as self-evident that first 'we' can know' (what the practice is or means) and secondly that as a consequence of 'our' determination of the practice's barbarity, there is a natural right to intervene (either morally or politically). ${ }^{18}$

By raising the issue, these early activists played a crucial role in determining hegemonic discourse about FGC and raising it to the level of the negotiation tables of international institutions such as the World Health Organization and United Nations agencies. Their tone was a fiercely rejecting one and very problematic for most activists coming from FGC practicing countries. Disputes in the late 1970s and 1980s at international meetings between African and Western feminists over the 'backwardness' of the practice have been well charted. ${ }^{19}$ African feminists and activists, however, have also contributed to the activist literature and awareness-raising against the practice. However, as Vicky Kirby notes, many of these works share common features and employ a similar style and language. She argues that 'books about genital excision written by African women carry a totalizing sense of national authenticity within the role of their author function'. ${ }^{20}$ She compares two books by two different authors 'almost identical in their medicalized arguments, research methods and bibliographical material' ${ }^{21}$ In this respect it is worthy of note how the work of renowned Egyptian feminist, Nawal El Saadawi, has been received and adapted in the West. The English translation of her book that mentioned FGC underwent significant changes from the Arabic original turning it into a worldwide success

\footnotetext{
${ }^{16}$ Boddy, 'Gender Crusades', 53; M. Dubois, 'The Governance of the Third World: A Foucauldian Perspective on Power Relations in Development' in Alternatives: Global, Local, Political 16:1 (1991), 1-30.

17 Kirby, 'On the cutting edge'.

18 Njambi, 'Irua Ria Atumia and Anti-Colonial Struggles Among the Gikuyu of Kenya', 693. This leads critical anthropologist Richard Shweder to castigate the global anti-FGM campaign by identifying it as driven by wealthy international donors, and First World women's and human rights activists. He finds that 'a discourse of horror is used that is similar in many ways to the missionary and colonial discourse of the 1920s'. R. Shweder, 'When Cultures Collide: Which Rights? Whose Tradition of Values? A Critique of the Global Anti-FGM Campaign' in C.L. Eisgruber and A. Sajo (eds.), Global Justice and the Bulwarks of Localism, Leiden: Martinus Nijhoff Publishers 2005, 198.

${ }_{19}$ African participants in these meetings generally accused those from non-practicing countries who were speaking against the practice of cultural insensitivity. They rejected the argument that the practice was 'backward' or that it represented women's subordinate position in society. See N. Berkovitch and K. Bradley, 'The Globalization of Women's Status: Consensus/Dissensus in the World Polity' in Sociological Perspectives 42:3 (1994), 481-498; K. Brennan, 'The Influence of Cultural Relativism on International Human Rights Law: Female Circumcision as a Case Study' in Law \& Inequality 7 (1989), 367-398; O. Koso-Thomas, The Circumcision of Women: A Strategy for Eradication, London: Zed Press 1987; E. Dorkenoo, Cutting the Rose: Female Genital Mutilation: The Practice and its Prevention, London: Minority Rights Group 1994.

20 Kirby, 'On the cutting edge', 38.

21 Ibid.
} 
and gaining a prominent position within US academia. ${ }^{22}$ This is not to be dismissive of African activist's work, but rather to make the point that it could only be heard when in perceived compliance with the hegemonic discourse. However, the central concern here lies rather with pointing to the consequences of location in knowledge and norm production. What stands out is the rather selective interest in voices from FGC practicing countries and the subsequent exclusion of alternative analyses and frameworks sceptical of the practice that resonate more with local understandings and which are not necessarily embedded within larger discourses of modernization and (economic) progress.

\section{International Norm Production}

After entering the international arena from the late 1970s onwards, discussion of FGC has seen a shift in focus from health care and health risks to a discourse of rights and violence against women. ${ }^{23}$ Berkovitch and Bradley discuss the debate prior to this period within international bodies on whether or not to tackle the issue. Some agencies such as World Health Organization (WHO) and the United Nations Children's Fund (UNICEF) were initially reluctant even to study the practice as they considered it outside of their competence. ${ }^{24}$ The question of disrespecting nations' sovereignty also prevented international institutions of studying or condemning the practice. ${ }^{25}$ It was only in 1979 at a WHO-sponsored seminar that the practices were condemned for the first time as a health haz$\operatorname{ard}^{26}$ and this opened the door for a broader discussion. Soon, however, the focus on health would give way to a rights discourse.

In the following period, the agenda of human rights expanded to include harm done to women by non-state, private actors. At the 1993 UN Conference on Human Rights in Vienna, women activists succeeded in having women's rights recognized as human rights. At the same time, female genital cutting became classified as a form of violence against women. Berkovitch and Bradley argue that the link between genital mutilation and global action was enabled after this redefinition of the practice and of the notion of human rights within the world polity. ${ }^{27}$ They argue that these redefinitions were necessary to coincide with the global project being set up in the early 1990s, centred on modernist

\footnotetext{
22 Saadawi's book Al-Wajh al-'ari lil-mar'a al-'arabiyyah' of 1977 was adapted and published in the US as 'The hidden face of Eve' in 1982. Two chapters 'Women's work at home' and 'The Arab woman and socialism' were omitted and the subject of FGC was prioritized and expounded, while it was only mentioned briefly in the original version. A. Amal, 'Framing Nawal El Saadawi: Arab Feminism in a Transnational World' in Signs 26:1 (2000), 215-249.

23 J. Horn, 'Not Culture but Gender: Reconceptualizing Female Genital Mutilation/Cutting' in W. Chavkin and E. Chesler (eds.), Where Human Rights Begin: Health, Sexuality and Women in the New Millennium, Piscataway, NJ: Rutgers University Press 2005; E. Boyle, Female Genital Cutting: Cultural Conflict in the Global Community, New York: Johns Hopkins University Press 2002; Hernlund and Shell-Duncan (eds.), Transcultural Bodies.

${ }^{24}$ Berkovitch and Bradley, 'The Globalization of Women's Status', 489.

25 Boyle, Female Genital Cutting.

${ }^{26}$ Berkovitch and Bradley, 'The Globalization of Women's Status', 489.

27 Ibid.
} 
notions of universalism, liberal individualism and rationalism. FGC became reconceived as an obstacle to girls' rights and education, and thus as an obstacle to national progress. In this manner, opposition to FGC was now articulated as consistent and compatible with the liberal individualist framework. This reconceptualization opened the door for global action. ${ }^{28}$

The Vienna Conference was an important preparatory meeting in the lead-up to the International Conference on Population and Development (ICPD) meeting the following year (1994) which was held in Cairo. It helped make the latter conference into what was widely seen as a significant success and achievement for women's bodily rights. The common declaration, the Cairo Programme of Action, that resulted from the conference clearly positioned FGC as a sexual and reproductive rights concern. Looking at issues such as fertility and population control policies through the lenses of sexual and reproductive health and rights was celebrated as a landmark paradigm shift in the sphere of international and intergovernmental institutions. ${ }^{29}$ In the aftermath of the organization of the ICPD, the Cairo Agreement stipulated the goal of eradicating FGC and thus firmly established the desirability of this eradication as a global norm in subsequent development discourse and practice. ${ }^{30}$

\section{The Egyptian Task Force against FGM and the Predicament of Catachresis}

It is against this background that I want to turn to the case of postcolonial Egypt. In this second part, the question is addressed how the above-described processes affects Egyptian activism today. What does Egyptian activism look like within a hegemonic anti-FGC discourse that is embedded in paradigms of modernization, civilization and liberal individualism? Does it rely on the same paradigms or does it try to move beyond them? Secondly, following from these questions, it is explored what it means to participate from within a postcolonial space in an anti-FGC campaign that is largely shaped, structured and funded by international institutions and private donor foundations. In short, I want to discuss how the politics of location operate with respect to globalized knowledge production. When the history of the claim/norm to abandon the ancient practice of FGC has been written in the West and through consensus-building

\footnotetext{
${ }^{28}$ This account of the UN deliberation and assessment of FGC is geared towards the overall treatment of the practice across the different organizational sections, agencies and commissions. There are also interesting examples of culturally-sensitive treatment of the subject in the late 1980s. See Brennan, 'The Influence of Cultural Relativism on International Human Rights Law'.

${ }^{29}$ W. Harcourt, Body Politics in Development, Critical Debates in Gender and Development, London: Zed Books 2000, 42.

${ }^{30}$ Fighting FGC is one of the components in the new UN development policy of fighting poverty expressed in the Millennium Development Goals of 2000. In December 2012 the United Nations General Assembly for the first time passed a resolution against the practice of FGC that was widely celebrated as an important new step in the global campaign for eradication. See http://www.un.org/ga/search/view_doc.asp?symbol=A/67/ PV.60 (accessed 22 July 2013).
}

Religion and Gender vol. 3, no. 2 (2013), pp. 222-239 
in international institutions, how does this predicate and complicate Egyptian proponents of this policy?

In what follows, I will draw on a two-month period of fieldwork in Cairo during September to November 2012 consisting of in-depth interviews with activists and policy makers and a document analysis of campaign material and press reports. The aim is not to offer a comprehensive overview of achievements and failures of Egyptian activism and policies. Rather, the focus lies in reconstructing crucial junctures in the course of Egyptian activism against FGC by unravelling the conditions that both enabled and limited it, against the background of the global campaign and its hegemonic international discourse and institutions. I first reconstruct the founding and activities of the Egyptian national Task Force against FGM and its subsequent cooptation by the state. Secondly, I discuss the limitations and possibilities resulting from the catachrestic claim of abandoning FGC in postcolonial Egypt and finally I reflect on the relation between Egypt's anti-FGC policy and religion.

\section{The Creation of the Task Force and its Cooptation}

The International Conference on Population and Development (ICPD) represents an essential juncture in both global norm-setting and in the particular genealogy of Egyptian activism against the practice of FGC. International public and political attention for FGC reached its peak during and after the conference in which the presence of female genital cutting practices in Egypt played a prominent role. In his address to the conference, the Egyptian Minister of Health stated that FGC was a dying practice in Egypt. One day later, however, CNN broadcast a video of the circumcision of a 13-year-old girl in Cairo. Consequently, the minister was pressured to declare his intention to confront the practice. ${ }^{31}$ The CNN screening was received nationwide as a public scandal and was felt as deeply humiliating. Both the film and the conference brought Egypt into the international limelight which embarrassed and put the Egyptian government under pressure. In 1995, the first Egyptian Demographic Health Survey (DHS) that included data on FGC revealed that $97 \%$ of women between the age of 15 and 40 had undergone some form of genital cutting. The American Congress pushed the International Monetary Fund (IMF) and the World Bank (WB) to link financial aid to reform efforts in the field of fighting FGC as early as 1996. ${ }^{32}$ The Egyptian government started to develop highly mediatized national campaigns in 2000, after five years of activism from 1994 until 1999 by the 'National Task Force against FGM', hereafter called the task force.

My fieldwork between September and November 2012 focused on the activities of the national task force and consisted of in-depth interviews with its former core group members. This diverse group of health and family planning professionals, self-described feminists, political activists and researchers became most identified with the cause of fighting FGC until the government started to develop a national policy in 2000. The topic had been earlier addressed in

\footnotetext{
31 A. Seif el Dawla, 'The Political and Legal Struggle over Female Genital Mutilation in Egypt: Five Years since the ICPD' in Reproductive Health Matters 7:13 (1999), 128-136.

32 Boyle, Female Genital Cutting, 41.
} 
Egyptian public debate in several ways, most famously by feminist writer and activist Nawal al Saadawi in the 1970s, but it failed to become a widely discussed and contended topic. ${ }^{33}$ During the ICPD in 1993 it was catapulted into the public arena in a highly sensationalist manner due to the CNN screening. FGC suddenly became publicly debated in the context of other controversial subjects such as reproductive rights, gender justice, homosexuality and abortion. This sensationalist entrée led to its subsequent politicization during the course of the task force's activities. ${ }^{34}$ The externally prompted, outspoken call for abandonment - by means of the ICPD - was answered by some conservative factions of within Egyptian society, stressing the cultural and religious importance of the practice.

The structure of the task force was set up immediately after the ICPD under the auspices of the National NGO Commission for Population and Development (NCPD) established in collaboration with the state to follow up on the Cairo Agreement, resulting from the ICPD. It was led by Aziza Hussayn, a renowned activist and family planning professional. ${ }^{35}$ The NCPD also hosted a task force on gender and another on sexual health. It was the task force against FGM, however, that was most active, visible and which continued working after the activities of the other groups dwindled. The extensive preparatory meetings before ICPD connected task force core members together with hundreds of other individuals from across the country. All my interviewees recognized the major impetus coming from the months-long preparations for the ICPD. This process created a unique moment of women group meetings, organizing and debating population policy, concepts of gender and women's bodily rights and FGC. It was also enabled by an unusual degree of state compliance in allowing this remarkable flourishing of civil society. ${ }^{36}$ One interviewee pointed out, however, how quickly the state took back that freedom after the ICPD: 'During the ICPD there was a relative freedom of movement that the government wanted to contain after the performance was over, of the conference. And that applied to all organizations, not only women's organizations'.

All interviewees were highly-educated individuals concerned with women's position in society, on health, reproductive rights and bodily integrity. They were already connected before the ICPD and the official launch of the task force. Its coordinator, Marie Assaad, whose activism and interest in fighting FGC had started in the 1950s, consciously opted to work within the NCPD frame because this provided her with a sense of security as a state recognized structure. Assaad emphasizes that she was fully aware of the restrictions and insecurities she would have faced when working within civil society or in any other form that could have invited adverse state attention. Both Aziza Hussayn and

\footnotetext{
${ }_{33}$ M. Badran, 'Body Politic(s): Women, Power and Sexuality in Egypt' in M. Badran, Feminism in Islam, Secular and Religious Convergences, London: Oneworld Publications 2009, 168-191.

${ }^{34}$ Seif el Dawla, 'The Political and Legal Struggle over Female Genital Mutilation in Egypt', 128; Badran, 'Body Politic(s)'.

${ }^{35}$ The Ford Foundation Cairo Office played a major role in providing grants for the NCPD and the task force and in lobbying the government to allow and establish these institutions to operate as intermediaries between the government and civil society. Letting Flowers Bloom: The Growth of Reproductive Health Efforts in Egypt, Cairo: The Cairo Office of the Ford Foundation, Sept. 2009, ix.

${ }^{36}$ Also see Boyle, Female Genital Cutting; Badran, 'Body Politic(s)', 174.
}

Religion and Gender vol. 3, no. 2 (2013), pp. 222-239 
Marie Assaad had been working on the issue of women's health and against FGC, but never caught national attention until the ICPD brought the practice under international attention. The aim of the task force was to engage society in a dialogue on the practice. It wanted to conduct research, disseminate information, raise awareness, train field workers and work on advocacy. Three committees were created, one on communication with policy makers, another on stimulating grassroots groups and a third one on research and study. The task force served as an intermediary between groups and activists based in the different governorates and the NCPD umbrella of ICPD follow-up institutions. ${ }^{37}$ It followed a 'gender equal development approach', meaning that the practice identified as Female Genital Mutilation (FGM) was identified as 'a social problem that represents violence against women and characterizes the dominancebased relationship between both genders'. ${ }^{38}$

Dialogue and research were strongly emphasised. There were five regional offices across the country to build up a country-wide network. Efforts were also made to embed their current negative attitudes towards the practice within a wider historical perspective. Different booklets and studies were published to show earlier challenges of the practice within Egyptian society. ${ }^{39}$ Members engaged in research to challenge long-standing truths about the practice, namely that FGC was mainly practiced and maintained by women on women, and in areas with high illiteracy. Their research showed - in congruence with the Demographic Health Survey reports of the following years - that it is increasingly being undertaken by doctors and medical professionals, and thus not by illiterate populations. Another point of focus was male attitudes towards the practice. One interviewee attributes these innovative approaches and new angles to the originality of the task force. She regrets that 'despite this research, the same interventions continue the same way they did [until today], awareness raising among women, training of women.'

The task force's activities were ended and the group was dissolved by its coordinator, Marie Assaad after five years. In her opinion the group had reached its limits and the cause of fighting FGC would be better promoted when elevated to the level of national policy making. A new space was created for anti-FGC activism within the National Council for Childhood and Motherhood (NCCM) presided by then First Lady Suzanne Mubarak, first by informal talks and then by the official participation of two old task force members. These experienced members started a process of negotiation within the NCCM to embark on a national-level program, namely the FGM Free Village Model, launched in 2003. The incorporation of the anti-FGM campaign by the NCCM opened many doors and provided access to state media and official state-appointed religious authorities. Subsequently, in the following years major changes were made, such as legislation that effectively criminalizes the practice in 2008 and the disapproval of the practice by Egypt's highest religious authorities in 2006.

\footnotetext{
${ }^{37}$ Toward FGM-free Villages in Egypt: A Mid-term Evaluation and Documentation of the FGM-Free Village Project, Cairo: Population Council 2010, 10-16.

${ }^{38} \mathrm{~N}$. Wassef, Da min zaman, Past and Present Discourses on FGM in Egypt, Cairo: FGM Task Force 1998, 4.

39 Ibid.
} 


\section{Catachresis: Limitations and Possibilities for Postcolonial Anti-FGC Activism}

Task force group members tried to connect as much as possible with Egyptian culture and society by dialoguing with women in different governorates and by emphasizing historical opposition within Egypt to the practice. They realized that the international campaign and the ICPD enabled much of their work by means of funds and moral support. This transnational link, however, also put them in difficult positions vis-à-vis the dominant civilizing discourse that often accompanied anti-FGC rhetoric. One of the interviewed members explains the following:

This is one of the things that was very strange to me when I was working on FGM, that when you talk to the women or the men involved [at home], you are unconditionally against FGM. You understand why they are doing it, and you are trying to address the arguments why they are doing it. Then you travel to international conferences and you find yourself almost defending the practice of FGM, you know, because there is this stereotyping you know, there is this reduction of the human being to savages yeah, and it is this attitude that drives you to defend something that you are actually challenging at home. It is this attitude that makes you also understand, that makes you agree with some of the arguments that your opposition inside the country is putting forward.

This activist experienced such a strong rejection of sensationalist and simplifying anti-FGC discourse that she heard at conferences in the 1990s, that it ironically almost led her to defend the practice. Civilizational discourse upsets her to the extent that it enables her to understand domestic proponents of the practice, and to mediate her feminist sensibilities. Feminist theologian Musa Dube characterizes this kind of challenge of engaging in feminist postcolonial practices, as confronting and rejecting indigenous oppressive practices, 'without joining the colonizing discourse of rejecting or demonizing every aspect of indigenous cultures'. ${ }^{40}$ For these practices to be simultaneously decolonizing, Dube considers they ought to 'arrest colonizing ideology packed in claims of religious conversion, Western civilization, modernization, development, democratization, and globalization'. ${ }^{41}$ On the other hand, this discussion shows the complexity of engaging in feminist postcolonial practices through the reclamation of certain political-cultural positions that fall within the legacy of 'colonizing ideology'. Task force members claim the abandonment of a cultural practice because it harms women without wanting to adhere to the colonizing legacy and ideology with which this position is associated, wherein we can begin to see the catachrestic nature of the activists' dilemma.

While task force activism has been created and enabled to carry out its activities within the framework of international rights activism and development discourse, members have been limited by the same logic. One consequence of the development and globalization logic was the NGO-isation of the fledgling anti-FGC activist group. Islah Jad's defines 'NGO-isation' of social and grassroots

\footnotetext{
${ }^{40}$ M.W. Dube, 'Postcoloniality, Feminist Spaces and Religion' in L. Donaldson and Kwok Pui-Lan (eds.), Postcolonialism, Feminism and Religious Discourse, London and New York: Routledge 2002, 116.

41 lbid.
} 
movements as a characteristic of neoliberal reform that pressures social movements into forming more structured, professionalized organizations with more clearly delineated activities, which mostly results in de-politicization of the movement. ${ }^{42}$ While the group functioned as a semi-independent movement, it relied heavily on foreign donor funds to conduct research and to build their organization and nation-wide network. One interviewee explained that this change was initially not expected or aimed at but was rather imposed on them in order to receive funds:

The FGM task force did not want to become institutionalized, or to have a structure, or to become registered. It was an informal forum, where people came to and paid for their transportation with their own money and the donors were so impressed but they wanted a structure, they wanted an institution...

She expressed uneasiness with this necessary transformation. Another member recounts how the NGO-isation of the task force affected her personally and eventually led to her exclusion. The task force embraced a common vision against FGC (and against its medicalization) while members occasionally differed in opinion in matters of strategy or analysis, which was generally experienced as fruitful. In her case, however, her diverging opinion also clashed with funding donor's expectancies. She supported the view that questioning FGC necessarily should go hand in hand with challenging male circumcision. Although she was not the only one who questioned male circumcision, she was most outspoken and vigorous about explaining and defending her views on bodily integrity and autonomy. She considers both male and female circumcision as part of gender constructions which she opposes. Opposing FGC for her necessarily entails opposing male circumcision as well: 'Gender is about body politics, it's one and the same thing. The patriarchal society aims to create an image of masculinity and femininity upon which gender roles are divided, and male and female circumcision are part of that'. This religiously controversial view that aims at abandoning both female and male genital cutting was, however, disliked by both Egyptian organizers of meetings to discuss FGC and by international donor agencies. Her deviant view gradually led to her exclusion from activities and ended her cooperation with the group after six years:

The exclusion happened gradually. I was often invited to panels and meetings, and then questions come from the audience about MGM [Male Genital Mutilation] and I would answer with the data that I know. Once, the organizers of the session, when I started to respond to the woman who asked [about MGM], said: stop, this is a session against FGM and it is financed to be against FGM and now you are taking minutes to speak about MGM, which is not ethical, what can we tell the funders? [...] The stakeholders told me, 'Ok fine, speak as you like but find other funders for your activity. Don't come to our activities which are funded for FGM and give your information'.

Obviously much can be said about the meaning of resisting both male and female genital cutting within a religious conservative society and the generally hostile feminist reception of this idea in the period of the task force. Suffice to say here is that MGM is not part of the international discourse of anti-FGC

42 I. Jad, 'The NGO-isation of Arab Women's Movements' in IDS Bulletin 35 (2004), 34-42. 
funding institutions and that these propositions challenge the existing campaigning framework. During the period of task force activity, individual members were able to express their personal analysis and points of concern. The task force leadership or the NCPD structure did not stop them from expressing personal opinions. Its coordinator Assaad refers to these events by saying that certain members' activities regularly 'embarrassed' the NCPD officials but that enough leeway existed that allowed regular upsetting of structures and individuals. ${ }^{43}$ This situation changed after the state co-opted the task force experience and initiated a national policy against the practice. Members disagree about this final decision. While some define it as state-cooptation that should never have happened, arguing that the cause of fighting FGC should have remained within civil society, others see it as a natural and positive step forward to reach a national audience. The new state initiative by the National Council of Childhood and Motherhood headed by Suzanne Mubarak drew heavily on the expertise and activism that the task force had gathered but excluded several of its most fervent members. One interviewee expresses it as follows:

those women who have dedicated their time and efforts to volunteer to raise the task force for it to have a strong position, we were never invited to the national conferences by the NCCM. The feminists were not invited. They rid themselves of the feminists, to put it bluntly ....[The task force leadership] felt that the state coming in would give a real push, but I disagree. I don't believe in this, the state does not give a real push unless someone is pushing them, that was what the task force was doing. You cannot guarantee a minister who is pro[banning FGC].

The new path that was taken by old group members was one of disciplined and skilful negotiation and entered more the sphere of diplomacy than that of activism. A patient continuation of their efforts in combination with support from crucial state-allied personalities would eventually lead to legislation effectively criminalizing FGC in 2008 and an unambiguous statement of disapproval of the practice by Egypt's Islamic authorities in 2006.

\section{Making FGC Un-Islamic}

In this final section I reflect on the relation between anti-FGC activism and religion. The relationship between the task force's anti-FGC activists and Islamic religious authorities has been a difficult one since the start of the ICPD preparations. More militant members soon found themselves involved in a court case against the head of Egypt's highest religious authority, the sheikh of al-Azhar. In 1994, after the ICPD conference was held and public attention to the practice was raised, the sheikh of al-Azhar, Gad al Haq, issued a fatwa stating that FGC is a duty under Islam comparable to the duty of prayer. A couple of task force members in coalition with human rights organizations filed a suit against him on charges of abusing his authority to the detriment of Egyptian women. ${ }^{44}$ While this episode represents the highest level of confrontation, the years after

\footnotetext{
${ }^{43}$ Interview by the Author 24 November 2012.

${ }^{44}$ A. Abdel Hadi, 'A Community of Women Empowered: the Story of Deir el Barsha' in R. Abusharaf (ed.), Female Circumcision: Multicultural Perspectives, Philadelphia: University of Pennsylvania Press 2006, 210.
}

Religion and Gender vol. 3, no. 2 (2013), pp. 222-239 
2000 show a more diplomatic approach as the state's NCCM had taken charge and after al-Azhar had a new leader.

Dialogue with religious authorities is a well-known strategy in the international campaign. FGC practices predate both Islam and Christianity and many campaigners thus target religious authorities to make clear statements about differentiating their religion from the cultural practice. Egyptian activism shows a similar focus on religious, Islamic, authorities. Progressive fatwas have been collected and published stating that there is no textual basis within the Islamic legal tradition that supports female genital cutting..$^{45}$ They state that the practice cannot be considered an obligatory or an honourable act due to a lack of authentic textual bases within Islamic tradition. Yet this conclusion allows for an interpretation that the practice is permissible, that it is not forbidden by Islam.

The efforts for convincing religious authorities to throw their support behind the campaign culminated in 2006. This international conference on Islam and FGC initiated by the German NGO Target and held at al-Azhar University brought together an unlikely alliance of major governmental representatives, a German non-governmental organization, Target, Islamic clerics including the grand mufti and sheikh of al-Azhar Muhammad Sayyed Tantawi, international Sunni Islamic authority sheikh Yusuf al Qaradawi and representatives of the National Council of Childhood and Motherhood, among whom were two previous members of the task force. The conference's final declaration, supported by grand mufti Ali al Gom'a, the head of Dar al Iftaa, the House of Fatwa Issuance, strongly condemned the practice as harmful and therefore forbidden by Islam. Furthermore, it 'urges regional and international organizations to exert efforts towards educating people and disseminating awareness of the health risks involved in this harmful practice', it 'calls on legislative institutions to enact a law prohibiting female circumcision and penalizing the perpetrator' and 'calls on international organizations and associations to provide all forms of assistance to the regions where female circumcision is practiced with a view to eliminating it'. 46

The language that is deployed in the final declaration strongly resonates with international anti-FGC campaigning discourse as it is used by the international community of campaigners. It explicitly invites regional and international organizations to educate and to provide assistance to Egypt. The importance of this declaration is that its discourse was also endorsed by Islamic religious authorities, and this is considered a major success by campaigning partners, the NCCM and Target Group NGO. In this manner, the Egyptian national campaign against FGC completely intertwines with the structure and discourse provided by international institutions. The state - by means of the National Council of Motherhood and Childhood - proved itself to be a loyal and successful supporter of

45 Different Egyptian fatwa concerning FGC have been issued since 1904 that concluded that Islamic legal tradition does not support FGC. S. Al - Awa, 'FGM in the context of Islam', Cairo: National Council for Childhood and Motherhood, undated. http://www. nccm-egypt.org/e9/e1869/e2357/e2358/infoboxContent2359/FGMintheContextoflslam. pdf (accessed 22 July 2013).

${ }^{46}$ The declaration can be found online on the website of Target Group: http://www. target-human-rights.com/HP-08_fatwa/index.php?p=fatwaAzhar (accessed 22 July 2013). 
the international campaign by recruiting these religious voices to the cause. It successfully made FGC un-Islamic, at least on a nominal, institutional level.

It is remarkable that both activists, the state and the international campaign place emphasis on the importance of religious leadership and their authoritative voices. Their prominent position does resonate with Islamic legal and discursive tradition. At the same time, however, the understanding of religion that is advanced, also corresponds with secularized conceptualizations of religion, evident in the hegemonic international anti-FGC literature. Here, the predominant question whether FGC is Islamic or not - seemingly to be answered in a definite and timeless manner - attests to a static and restrictive conceptualization of religion, emphasizing belief, tenets, legal tradition and text. It precludes more dynamic understandings of religion in which one's behaviour and conviction is shaped by social and cultural dynamics and individual interpretation of Islamic tenets and ethics. For example, Richard Gauvain discusses the rejection of FGC by some salafi women based on their understanding of Islam in which 'khitan [FGC] is irreconcilable with Islam's fundamental kindness towards women, and, despite its appellation, should not really be described as an act of purification. ${ }^{47}$ In other words, by being subsumed under a secularized understanding of religion as evident in international campaign discourse, the relation between activism and religion is generally understood as one of conflict. Thus, the operational assumption is that leaders ought to be convinced to declare that the practice is not a religious one. Another kind of relation in which religion positively figures as a basis for opposing the practice is usually not part of the imagery. The catachrestic tension between acceptance of hegemonic discourse and local appropriation and modification is then least expressed in the domain of religion.

\section{Conclusion}

In this paper I have explored Gayatri Spivak's characterizations of catachresis within the context of Egyptian activist claims for the abandonment of the cultural practice of female genital cutting (FGC). In my discussion of catachrestic claims I refer to conscious acts of intervention in society and the making of feminist political claims - namely to stop the cultural practice of female genital cutting. Spivak describes catachresis as the reclamation of 'a series of regulative political concepts, the supposedly authoritative narrative of whose production was written elsewhere, in the social formation of Western Europe' ${ }^{48}$ In this paper, I have argued that the international campaign against FGC is in fact of Western provenance and that this greatly impacts and complicates Egyptian activists' work against the practice.

Sally Merry uses the term 'vernacularization' of rights discourses to describe the processes that 'translate' global discourses and adapt them to local institutions and meanings. She discusses 'the appropriation of women's human rights

\footnotetext{
${ }^{47}$ The popular denomination of FGC is 'tahara', which means purification. R. Gauvain, Salafi Ritual Purity: In the Presence of God, London and New York: Routledge 2013, 200-201.

${ }^{48}$ Spivak, 'Poststructuralism, Marginality, Postcoloniality and Value', 225.
}

Religion and Gender vol. 3, no. 2 (2013), pp. 222-239 
to analyze the process by which human rights are remade in the vernacular' and develops an ethnography of actual practices of human rights. ${ }^{49}$ Similarly, Homi Bhabha's notion of hybridity as 'subversive mimicry' also bears on the complexities of postcolonial activism and its transformation of colonial conceptualizations. While I am also interested in the act of mediation and transformation of discourse originating in the transnational and the global into an Egyptian context, my main concern, however, has been less on its translation itself than on outlining its conditions of possibility, the structures and limits that are formed and the subsequent exclusion of the development of alternative epistemologies that are halted or not able to take shape. The concept of catachresis and its foregrounding of the question of location and power in knowledge and norm production enables such an analysis.

The first part of the paper traced the production of knowledge on the practice of female genital cutting within European colonial and postcolonial history. Important colonial precedents of intervention in regulating and reducing the practice created a discourse that is undergirded by schemes of civilization, modernization and progress. A few decades of inattention then passed in which international institutions held back from interference into what they saw as cultural and religious matters of nation-states. Western second-wave feminism broke this barrier by castigating the practice as a manifestation of global patriarchal control over women's bodies and calling for global action. United Nations institutions hesitantly discussed the practice, culminating in several condemnations of the practice as a violation of women's rights and a form of violence against women in the 1990s. Anti-FGC action became a global norm, couched in terms of modernization, universalism and liberal individualism.

Against this background, I have discussed Egyptian activism focusing on the group of women and men which became nationally most identified with the cause of fighting FGC and who formed the national 'Task Force against FGM' in 1994 until its disbandment in 1999, followed by a state-cooptation of the campaign. I argue that task force members creatively carved out a scope of action for themselves, that allowed for a diversity of both militant feminists, political activists and pragmatics. Its work was structurally enabled and supported by the international institutions which funded and shaped hegemonic campaigning discourse. At the same time, members struggled with the lines set out by this internationalist discourse. Some activists find themselves at odds with the civilizing tone that was heard at international conferences. The structure of NGO work as opposed to a grassroots movement had the effect of streamlining members' activities and speech. Another form of silencing occurred when activism against FGC was taken out of the arena of civil society and incorporated into state policy. Only activists with a depoliticized pragmatic stance on fighting FGC - and thus most aligned with hegemonic discourse - were included and coopted in the new national initiative presided over by the then First Lady Suzanne Mubarak. After state co-optation, relations between official (state-appointed) religious authorities and the national campaign improved and culminated in the strongest condemnation of the practice by Egypt's Islamic leaders. This focus on persuading religious authorities is an important characteristic of the

49 S.E. Merry, 'Transnational Human Rights and Local Activism: Mapping the Middle' in American Anthropologist 108:1 (2006), 39. 
international campaign. It confirms a general secularized understanding of religion that emphasizes belief as opposed to praxis and additionally disregards the more complex cultural and political dynamics that shape religious experience and identity. What we can see, to conclude, from the activism of the anti-FGC taskforce is an attempt to make local claims for the abandonment of the practice that accord with Egyptian values whilst at the same time speaking to and within a globalized (and residually colonialist) context of anti-FGC campaigning. It is this negotiation of the globalized structures with a vernacular discourse that tries to preserve or formulate its own heterogeneity that we could characterize as a catachrestic exercise in postcolonial resistance.

\section{Acknowledgement}

I would like to thank the organizers and participants of the workshop 'Catachreses? Gender, Religion and Postcoloniality', hosted by the Center for Gender and Religions Research at SOAS, University of London, 17-19 December 2012 for their interesting comments and questions. I am also grateful to Prof. Anne-Marie Korte and the participants of the Netherlands School for Advanced Studies in Theology and Religion PhD Text Reading seminar 'The Challenge of Difference: Postcolonial Theory in the Study of Religion and Gender' of 12 April 2013 for the many comments and an engaging discussion on an earlier version of this paper. Finally, I would like to thank the anonymous reviewers as well as Prof. Chia Longman and Prof. B. Scherer for reading and commenting on earlier versions of this article. 